\title{
Homeostatic properties of Lactobacillus jensenii engineered as a live vaginal anti-HIV microbicide
}

\author{
Hidemi S Yamamoto ${ }^{1}$, Qiang $\mathrm{Xu}^{2}$ and Raina N Fichorova ${ }^{1 *}$
}

\begin{abstract}
Background: Vaginal probiotics are investigated as a binary strategy for prevention of bacterial vaginosis and HIV. We applied an innovative experimental model using primary and immortalized human cervical and vaginal epithelial cells to assess the functional properties of Lactobacillus jensenii, a predominant constituent of the healthy vaginal microbiome, engineered to express the HIV-1 entry inhibitor modified cyanovirin-N (mCV-N). In this model bacteria colonize the epithelial cells over a period of 24-72 h. Staurosporine and the Toll-like receptor 2/6 ligand macrophage-activating lipopeptide-2 (MALP-2) serve as positive controls for apoptosis and proinflammatory activation, respectively. In 24-hour intervals, the colonized epithelium is assessed microscopically, supernatants are collected for measurement of soluble immunoinflammatory mediators and production of CV-N, and cells are lysed for assessment of: 1) apoptosis by cleaved versus total caspase-3 assay; 2) NF-kB activation by a luciferase reporter assay; or 3) epithelia-associated colony forming units (CFU) in Brucella agar.

Results: Wild type (WT) L. jensenii 1153 consistently colonized cervical and vaginal cells in the absence of epithelial damage and apoptosis. The bioengineered derivatives expressing mCV-N or control plasmids showed the same stable colonization pattern, which was reproducible between technologists and bacterial batches (CFU coefficient of variation $<10 \%$ within and between experiments and epithelial cell types). MALP-2 activated NF-KB and caused fold-increased levels of proinflammatory mediators with clinically established significance in the cervicovaginal environment (IL-1 $a, I L-1 \beta, I L-6$, TNF- $a, I L-8$, RANTES, MIP-3a, and ICAM-1), measured by a multiplex electrochemiluminescence assay. At the same time levels of protective anti-inflammatory mediators interleukin 1 receptor antagonist (IL-1RA) and secretory leukocyte protease inhibitor (SLPI), both measured by ELISA, remained constant (IL-1RA) or moderately increased (SLPI). Similarly to MALP-2, colonization by L. jensenii WT activated NF-KB; however, unlike the synthetic TLR2/6 ligand, the live microorganisms did not induce significant changes in the secreted levels across all inflammation-associated proteins. The mCV-N production and function were confirmed by western blot and a HIV-1 gp120 binding assay, respectively. The bioengineered lactobacilli expressed mCV-N with anti-HIV activity preserved in the epithelial cell context and caused no significant immunoinflammatory changes as compared to the WT L. jensenii.
\end{abstract}

Conclusions: These results highlight the translational value of the colonization model and justify further clinical investigation of the homeostatic and anti-HIV effectiveness of the L. jensenii derivates.

\footnotetext{
* Correspondence: rfichorova@rics.bwh.harvard.edu

'Laboratory of Genital Tract Biology, Department of Obstetrics, Gynecology and Reproductive Biology, Brigham and Women's Hospital, Harvard Medical School, 221 Longwood AvenueBoston, MA, USA

Full list of author information is available at the end of the article
}

\section{Biomed Central}

(c) 2013 Yamamoto et al.; licensee BioMed Central Ltd. This is an Open Access article distributed under the terms of the Creative Commons Attribution License (http://creativecommons.org/licenses/by/2.0), which permits unrestricted use, distribution, and reproduction in any medium, provided the original work is properly cited. 


\section{Background}

Topical microbicides have been investigated as a leading prevention strategy in the HIV/AIDS pandemic, which currently affects 34 million people around the globe [1]. A number of compounds with broad-spectrum anti-HIV activity in-vitro have successfully passed preclinical and Phase I evaluations, nevertheless, those selected for Phase II/III trials have failed to prevent HIV thus far [2-6]. Anti-retrovirals with more specific anti-HIV activities have also been explored; however, tenofovir, the only topical gel candidate tested in Phase II/III settings as of yet, had initially demonstrated marginal (39\%) effectiveness [7], but has most recently been discontinued due to futility [8].

The impracticality and numerous pharmacokinetic difficulties of the coitally- related dosing strategy are shortcomings of the conventional gel-based microbicides $[2,3,7,9,10]$. Gels may not efficiently cover the entire genital tract mucosal surface vulnerable to HIV entry. Typically gels require application shortly before intercourse to be protective and frequently may require re-application to counter the effects of dilution, degradation or rapid clearance [11]. On the other hand, frequent exposure of the vaginal environment to foreign substances can have toxic effects and damage the epithelial membranes resulting in irritation and undesirable inflammatory responses increasing the risk of HIV acquisition [12]. A solution to these shortcomings may be offered by bioengineered probiotic products based on vaginal/rectal commensal organisms that are capable of delivering anti-HIV factors in a sustainable, non-inflammatory, self-renewing mechanism directly at the point of viral infection [13-19].

This study applied an innovative experimental model of microbiota colonized epithelium [20] to assess the immunoinflammatory properties of a probiotic-based anti-HIV microbicide. Osel, Inc (Mountain View, CA) has genetically engineered Lactobacillus jensenii, one of the predominant components of the normal vaginal microbiota $[21,22]$, to express a modified version of the anti-HIV Cyanobacterium protein Cyanovirin-N (mCVN) [15]. The natural CV-N protein interrupts HIV-1 membrane fusion by impairing CD4 independent and dependent binding of gp120 to the HIV-1 co-receptors CCR5 and CXCR4 [23,24]. Pusch et al. demonstrated HIV-1 inhibition in-vitro with another modified version of CV-N expressed by L. plantarum and Lactococcus lactis [16]. The bioengineered $\mathrm{mCV}-\mathrm{N}$ invented by Osel Inc. irreversibly inactivates both CXCR4 and CCR5 tropic HIV strains in-vitro [15,23]. L. jensenii expressing $\mathrm{mCV}-\mathrm{N}$ at concentrations of $7 \times 10^{8} \mathrm{CFU} / \mathrm{ml}$, mimicking the natural $L$. jensenii concentrations found in women [25], completely inhibited CCR5 tropic HIV-1 entry invitro $[15,26]$. Both the natural $\mathrm{CV}-\mathrm{N}$ and $\mathrm{mCV}-\mathrm{N}$ are inhibitory against T-tropic, M-tropic and dual T and Mtropic primary clinical strains of HIV-1 and T-tropic laboratory adapted strains of HIV-1 and HIV-2 in-vitro $[15,23]$. L. jensenii 1153 was selected as a parental strain due to it's growth, colonization rates and inherent probiotic properties [15]. Our study is the first to assess simultaneously the colonization and immunomodulatory properties of 1153 and its $\mathrm{mCV}-\mathrm{N}$ producing derivatives in the human vaginal epithelial cell context. Hereby we tested the hypotheses that: 1) an in-vitro model can mimic key components of the microbiota-epithelial interactions in a sustained reproducible manner allowing comparison of multiple bioengineered strains, 2) genetically engineered $L$. jensenii strains can deliver a bioactive anti-HIV peptide in the context of an unharmed homeostatic epithelial-commensal microenvironment.

\section{Methods}

\section{Bacterial strains}

The parental wild type (WT) L. jensenii 1153 human vaginal isolate and five experimental derivatives (Table 1) were obtained from Osel, Inc (Mountain View, CA). The generation of the bioengineered strains was previously published [15].

\section{Control test agents}

The synthetic macrophage-activating lipopeptide-2 (MALP-2) (Alexis Biologicals, San Diego, CA), a known Toll-like receptor (TLR) 2/6 ligand, was used at $50 \mathrm{nM}$ as a pro-inflammatory control [20,27]. Staurosporine (Sigma-Aldrich, St. Louis, MO) was used at $1 \mu \mathrm{M}$ as a pro-apoptotic agent [20,28,29].

\section{Epithelial models}

Human immortalized endocervical (End1/E6E7) and vaginal (Vk2/E6E7) epithelial cell lines were grown in antibiotic-free keratinocyte serum-free medium (KSFM) (Invitrogen, Carlsbad, CA) supplemented with bovine pituitary extract, epidermal growth factor and calcium chloride as described [30]. These immortalized cell lines have been previously shown to closely resemble the columnar (End1/E6E7) and stratified squamous (Vk2/E6E7) epithelial differentiation patterns and immune responses of primary cells and normal tissues of origin [30-36]. Polarized tissue constructs VEC- $100^{\mathrm{TM}}$ derived from primary ectocervical/vaginal epithelial cells, previously depicted immune properties comparable to that of normal tissues of origin $[37,38]$ were purchased from MatTek Corporation, Ashland, MA. The VEC-100 ${ }^{\text {тм }}$ tissues were maintained in antibiotic-free medium provided by MatTek. 
Table 1 Bioengineered $L$. jensenii derivatives with the expression cassette stably integrated into the bacterial chromosome

\begin{tabular}{|c|c|c|c|}
\hline \multirow[t]{2}{*}{ Strain } & \multirow[t]{2}{*}{ Integration Site } & \multicolumn{2}{|c|}{ Expression Cassette } \\
\hline & & Promoter & Integrated gene \\
\hline L. jensenii $1153^{a}$ & $N A^{b}$ & NA & NA \\
\hline L. jensenii 1153-1666 & pox1 & $r p s U$ & APVT-CV-N (P51G) \\
\hline L. jensenii 1153-2666 & pox1 & ptsH & APVT-CV-N (P51G) \\
\hline L. jensenii 1153-3666 & рерО & rpsu & APVT-CV-N (P51G) \\
\hline L. jensenii 1153-1646 & pox1 & gus $A$ & Gus A ( $\beta$-glucoronidase) \\
\hline L. jensenii 1153-GFP & poxi & $\operatorname{rps} U$ & EGFP \\
\hline
\end{tabular}

${ }^{a}$ Parental L. jensenii strain; ${ }^{b} \mathrm{NA}=$ not applicable (wild type strain); ${ }^{\mathrm{c} e n h a n c e d}$ green fluorescent protein.

\section{Recovery of cryopreserved wild type bacteria and bioengineered derivatives}

Multiple aliquots from three separate batches of $L$. jensenii WT and derivatives were received frozen from Osel, Inc and stored at $-80^{\circ} \mathrm{C}$ until tested. Each batch was examined in a minimum of three independent experiments. All strains were tested simultaneously by comparison of colony forming units (CFU) before use in our epithelial colonization model. For that purpose, one aliquot per strain from each batch was thawed, washed once in PBS by centrifugation, serially diluted in PBS and plated onto Brucella-based agar plates (PML Microbiologicals, Wilsonville, OR). Plates were incubated in an anaerobic chamber (Coy Laboratory Products Inc., Grass Lake, MI) containing an atmosphere of $10 \%$ carbon dioxide, $10 \%$ hydrogen, $80 \%$ nitrogen at $37^{\circ} \mathrm{C}$ for $24 \mathrm{~h}-48 \mathrm{~h}$ (until visible colonies formed), followed by CFU counting. Percent recovery of viable bacteria was determined in comparison to CFU counts obtained prior to cryopreservation by Osel, Inc.

\section{Epithelial colonization}

L. jensenii suspensions were prepared in antibiotic-free KSFM (Invitrogen) at $7 \times 10^{6} \mathrm{CFU} / \mathrm{ml}$ to colonize epithelial surfaces for $24 \mathrm{~h}, 48 \mathrm{~h}$ and $72 \mathrm{~h}$ as previously described for other vaginal bacteria [20]. In the immortalized cell line model, epithelial monolayers were grown to $100 \%$ confluence in 96-well plates (Fisher Scientific, Pittsburgh, PA) and bacterial suspensions $(0.1 \mathrm{ml})$ were added to achieve a multiplicity of infection of $\sim 10: 1$. In the VEC $-100^{\mathrm{TM}}$ model, tissue inserts were placed over $0.5 \mathrm{ml}$ medium in 12-well plates (Fisher Scientific) followed by addition of $0.156 \mathrm{ml}$ bacterial suspension to the apical epithelial surface. The bacterial-epithelial cocultures were incubated for $24 \mathrm{~h}-72 \mathrm{~h}$ under anaerobic conditions generated by AnaeroPack System (Mitsubishi Gas Chemical Co. Inc., New York, NY), at $35^{\circ} \mathrm{C}$ on an orbital shaker. Cell culture supernatants from the immortalized epithelia and basal chamber culture fluids from the VEC-100 tissue model were collected in $24 \mathrm{~h}$ time intervals for measurement of soluble immune mediator levels and $\mathrm{mCV}-\mathrm{N}$ as described below. At the end of each $24 \mathrm{~h}$ period the cells/tissue were washed and used for enumeration of epithelia-associated CFU (see below), or medium was reapplied and cultures were returned to anaerobic chamber for additional $24 \mathrm{~h}$ incubations. In some experiments, the cells were lysed for assessment of NF-kB activation or apoptosis (see sections below).

\section{Transmission electron microscopy}

Vk2/E6E7 cells were seeded on Aclar embedding film (Ted Pella Inc. Redding CA) and colonized with L. jensenii strains for $24 \mathrm{~h}$. A TecnaiG2 Spirit BioTWIN transmission electron microscope (FEI Company, Hillsboro, OR) was used to visualize bacterial-epithelial colonization, confirm morphological integrity and a lack of apoptosis as previously described [20].

\section{Epithelium-associated CFU enumeration}

Association of viable lactobacilli with epithelial cells was assessed by CFU counts as described in detail elsewhere [20]. In brief, at the end of each time period, the cultures were washed twice with ice-cold PBS and hypotonically lysed for $15 \mathrm{~min}$ in ice-cold HyPure water (Fisher Scientific), followed by adjustment of osmolarity with $2 \times$ concentrated PBS (Invitrogen). Serial dilutions were prepared in PBS and $30 \mu \mathrm{l}$ of each dilution was inoculated on Brucella-based agar plates (PML Microbiologicals). The plates were incubated in an anaerobic chamber (Coy Laboratory Products Inc) containing an atmosphere of $10 \%$ hydrogen, $10 \%$ carbon dioxide and $80 \%$ nitrogen at $37^{\circ} \mathrm{C}$ for $24 \mathrm{~h}-48 \mathrm{~h}$ (until visible colonies were formed), followed by CFU counting. CFU per $\mathrm{cm}^{2}$ epithelial surface area were calculated.

\section{NF-KB activation luciferase reporter assay}

Endocervial epithelial cells stably transfected with pHTSNF- $\mathrm{kB}$ firefly luciferase reporter vector (Biomyx Technology, San Diego, CA) as described [34] were grown in 96-well plates in hygromycin selection medium until confluence and then colonized with L. jensenii strains as 
described above. After 24 h, supernatants were collected, cells were lysed with GloLysis buffer and luciferase activity was determined using the Bright-Glo Luciferase Assay System by manufacturer's protocol (Promega, Madison, WI).

\section{Caspase-3 assay}

Vaginal epithelial cells (Vk2/E6E7) were treated with bacteria, MALP-2 (50 nM) and the proapoptotic agent staurosporine $(1 \mu \mathrm{M})$ to serve as a positive control. At the end of each incubation period, the epithelial monolayers were lysed in Tris lysis buffer containing protease inhibitor cocktail provided by Mesoscale Discovery (MSD), Gaithersburg, MD, per manufacturer's protocol. Levels of cleaved and total caspase-3 were measured simultaneously in each cell lysates using an MSD electrochemiluminescence (ECL) mutliplex assay and Sector Imager 2400 with Workbench software (MSD).

\section{Soluble immune mediators assays}

Concentrations of interleukin (IL- $1 \alpha$, IL-1 $\beta$, IL-6, TNF$\alpha$, IL-8, RANTES, MIP-3 $\alpha$, and ICAM-1) were measured in cell culture supernatants simultaneously using an MSD multiplex assay, Sector Imager 2400, and Workbench software. Levels of IL-1 receptor antagonist (IL1RA) and the antimicrobial peptide secretory leukocyte protease inhibitor (SLPI) were measured by Quantikine ELISA (R\&D Systems, Minneapolis, MN) using a Victor ${ }^{2}$ reader (Perkin Elmer Life Sciences, Boston, MA).

\section{mCV-N detection and functional recovery}

Cell culture supernatants collected from the vaginal and cervical colonization models were sterilized through 0.2 micron PharmAssure's Low protein binding syringe filters with HT Tuffryn Membrane (Pall Corporation, Port Washington, NY). Western blot analysis of the filtered supernatants was performed as described [13] to ensure full length expression of $\mathrm{CV}-\mathrm{N}$ in the experimental model, and to rule out loss of protein to filtration. The filtered sterile supernatants were subjected to a gp120 binding assay to confirm the presence of functional $\mathrm{mCV}-\mathrm{N}$ in the epithelial context. In brief, 96-well plates (Aalto Bio, Dublin, Ireland) coated with anti-HIV-1 gp120 antibody bound to recombinant gp120 (Protein Sciences, Meriden, CT) were incubated with undiluted cell culture supernatants for $2 \mathrm{~h}$ to allow for gp120 binding. Bound molecules were detected by rabbit anti$\mathrm{mCV}-\mathrm{N}$ and anti-rabbit horseradish peroxidase (HRP) (Alpha Diagnostics, San Antonio, TX) as described [13].

\section{Statistical analysis}

One-way ANOVA with Bonferroni multiple comparisons analysis were performed using GraphPad Prism version
4.00 for Windows (GraphPad Software, San Diego CA). $P$ values $<0.05$ were considered significant.

\section{Results}

L. jensenii reproducibly and consistently associates with the primary and immortalized cervicovaginal epithelial cells in the absence of apoptosis

Both parental and experimental strains of $L$. jensenii 1153 colonized morphologically intact epithelial cell monolayer observed by light microscopy at the end of each time period. Transmission electron microscopic images were obtained $24 \mathrm{~h}$ post colonization (Figure 1a). The lack of bacteria-induced apoptosis in our model was confirmed by assessment of cleaved versus total caspase 3 , showing significant increases of cleaved caspase 3 only by the staurosporine control (Figure 1b).

\section{a}
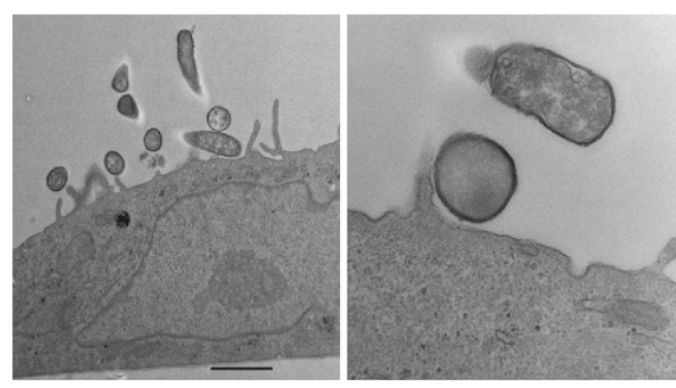

b

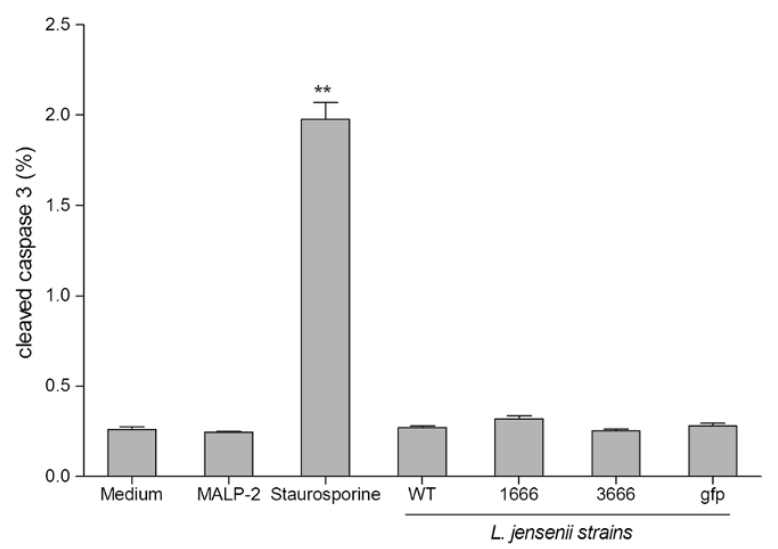

Figure 1 Lactobacillus strains consistently associate with the human epithelial model in the absence of apoptosis. (Figure 1a) Transmission electron microscopic image illustrates clear association between the $L$. jensenii electron dense bodies and the morphologically intact vaginal epithelial cells. No morphological signs of apoptosis are present. Bar represents 2 microns with a magnification of $\times 4800$. (Figure 1b) Caspase-3 cleavage represented by \% cleaved over total caspase harvested from vaginal (Vk2/E6E7) epithelial lysates after $24 \mathrm{~h}$ colonization with L. jensenii 1153 wild type (WT) and bioengineered L. jensenii 1153-1666, 3666 and gfp strains or treatment with $1 \mu \mathrm{M}$ Staurosporine positive control. Bars display means and SEM from triplicate cultures in one of three experiments. ${ }^{*} P<0.01$ different from medium control. 
All L. jensenii strains demonstrated reproducible recovery from frozen bacterial stocks measured by CFU. No variation was found due to performing technicians or dilutions in multiple bacteria batches tested (Figure 2a).

Wild type L. jensenii and all bioengineered derivatives reproducibly generated similar epithelial cell associated CFU counts. Comparable results were obtained with the primary polarized/stratified VEC-100 tissue model as with the immortalized cervical and vaginal epithelial monolayer

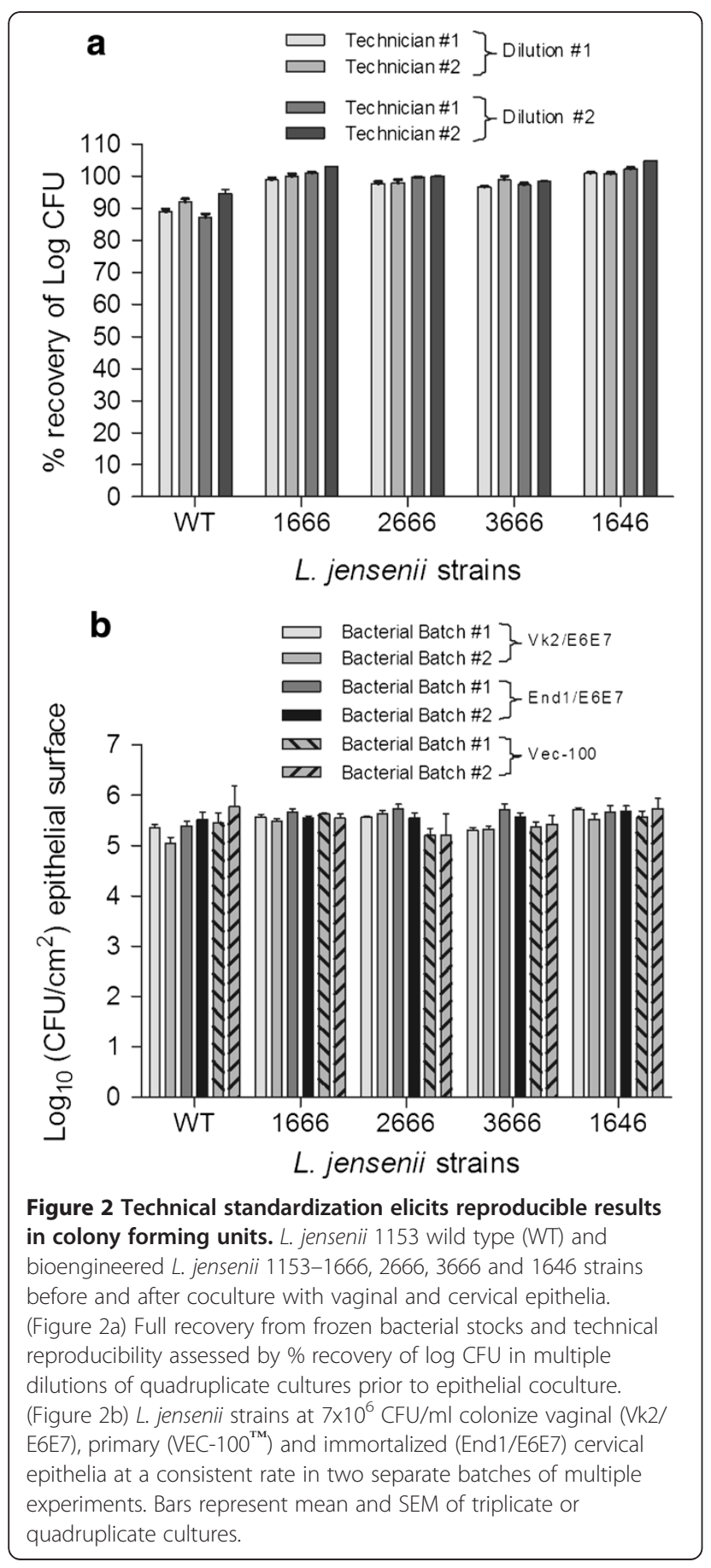

models. These results were confirmed by comparable colonization rates in multiple experiments with two separate batches of WT and bioengineered bacteria (Figure 2b).

\section{Wild type and bioengineered $L$. jensenii strains induced NF-KB activation but not proinflammatory protein production}

In order to compare the proinflammatory potential of the WT and derivative bacterial strains, we first examined their effects on the endocervical epithelial cell line stably transfected with the NF-kB-driven luciferase reporter gene in the first $24 \mathrm{~h}$ of bacterial-epithelial coculture. Luciferase was measured in cell lysates and IL-8 and SLPI were measured in the paired cell culture supernatants from the same cultures. All bacterial strains caused NF- $\mathrm{BB}$ driven luciferase activity similar to that induced by the TLR2/6 ligand MALP-2 (Figure 3a) at significantly $(P<0.001)$ higher levels than the sterile medium control ( 4-fold increase). However, only MALP-2 induced a significant $(P<0.01)$ IL-8 increase ( $>30$-fold) as compared to the medium (no bacteria) control (Figure 3b). MALP-2 alone induced a significant $(P<0.05)$ although moderate $(<2$-fold $)$ increase in SLPI levels measured in the same endocervical cultures as compared to the WT L. jensenii (Figure 3c). IL-8 and SLPI levels were not significantly changed by colonization with both the WT and mCV-N expressing bacteria as compared to medium control.

To confirm these findings in the primary tissue model, we treated VEC-100 ${ }^{\mathrm{TM}}$, Vk2/E6E7 and End1/E6E7 cells simultaneously with medium, MALP-2, the WT and bioengineered $L$. jensenii derivatives (Figure 4). Again, MALP-2, in contrast to $L$. jensenii, induced a significant IL-8 upregulation in all three models. Since the findings in the primary tissue model (Figure 4a) mirrored those in the immortalized epithelial monolayers (Figure $3 \mathrm{~b}$ and $4 \mathrm{~b}$ ), as previously reported with other vaginal bacteria [20], we chose the immortalized cell line model for further analysis of immunity mediators and CFU counts based on its lower cost- and handling time efficiency.

In further immune mediator analysis of $L$. jensenii colonized Vk2/E6E7 immortalized epithelial monolayers; MALP-2 induced significant increases over baseline levels of TNF- $\alpha(P<0.001)$ and IL-6 $(P<0.001)$, while the WT and derivatives had no significant effect on either (Figure 5a-b). IL-1 $\alpha$ levels slightly increased $(P<0.05)$ in the presence of the WT, however all derivatives maintained baseline levels (Figure $5 \mathrm{c}$ ). No significant differences were observed in IL-1RA levels (Figure 5D).

\section{Sustained bacterial colonization by wild type and bioengineered $L$. jensenii does not alter levels of inflammation-associated proteins over time}

To determine if the homeostatic effect of L. jensenii on innate immunity proteins is sustained over time, despite 


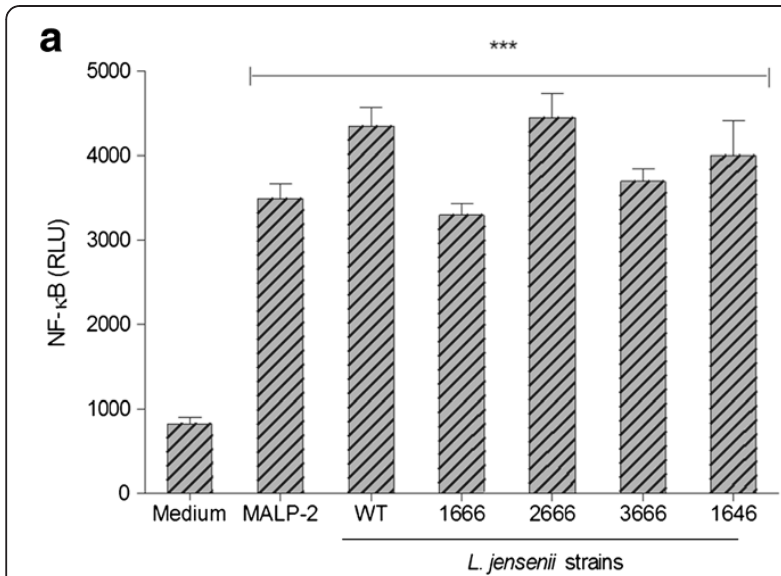

\section{b}

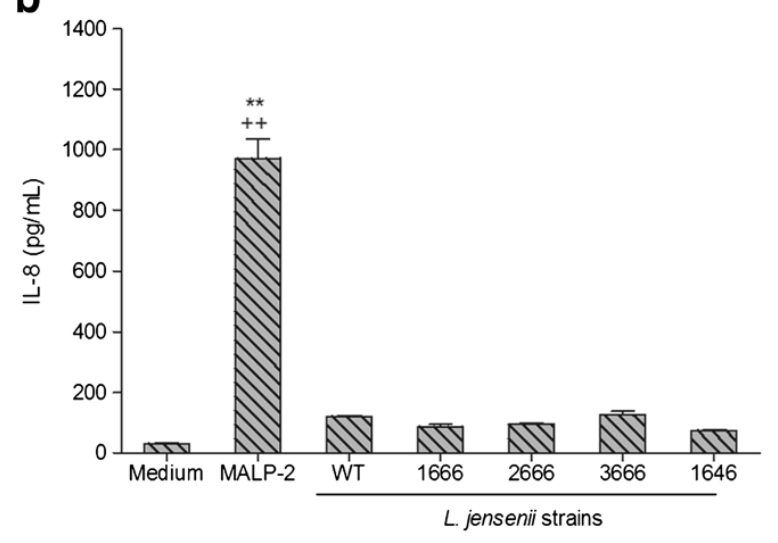

c

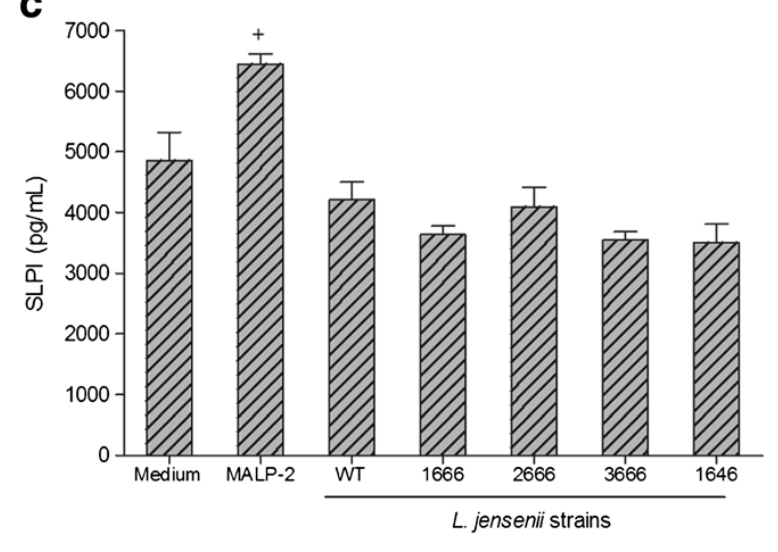

Figure 3 L. jensenii induced NF-KB expression without

immunogenic response. $24 \mathrm{~h}$ lysates and supernatants harvested from endocervical (End1/E6E7) epithelial cells cultured with $7 \times 10^{6} \mathrm{~L}$. jensenii 1153 wild type (WT), bioengineered L. jensenii 1153-1666, 2666, 3666 and 1646 strains or MALP-2 (50 nM) as a positive control. (Figure 3a) Luciferase activity measured in lysates from triplicate cultures in one representative of five experiments. Bars represent means and SEM ${ }^{* * *} P<0.001$ different from medium control.

(Figure $3 b$ ) IL-8 production analyzed in corresponding supernatants, bars are means and SEM from duplicate cultures in one representative of 11 experiments ${ }^{*} P<0.01$ different from medium control, ${ }^{++} P<0.01$ different from $L$. jensenii WT. (Figure 3c) SLPI detected in the same supernatants, bars are mean and SEM of duplicate cultures in one representative of six experiments ${ }^{+} P<0.05$ different from L. jensenii WT.

cultures of $L$. jensenii-colonized vaginal epithelial cells over the extended period of $72 \mathrm{~h}$ (Figure 6a). The WT and derivatives maintained steady baseline IL-8 levels at $24 \mathrm{~h}, 48 \mathrm{~h}$, and $72 \mathrm{~h}$ with no significant differences observed between the WT and bioengineered bacteria (Figure 6b). As expected, MALP-2 increased IL-8 significantly in the first $24 \mathrm{~h}$ time point as compared to both medium control and wild-type colonized bacteria $(P<0.001)$, and after its removal at $24 \mathrm{~h}$, the IL-8 levels returned to normal the end of the $72 \mathrm{~h}$ period.

To determine if the lack of proinflammatory protein upregulation over time is a broader phenomenon in the $L$. jensenii colonized vaginal epithelium we expanded our analysis using a multiplex MSD assay to quantify in the same supernatants more mediators known to be associated with the different steps of inflammatory cascades in the female genital tract e.g. pro-inflammatory cytokines IL-1 $\beta$ and IL- 6 , anti-inflammatory protective mediators e. g. IL-1RA, adhesion molecules e.g. sICAM-1 and chemokines MIP-3 $\alpha$ and RANTES. As shown in Figure 7, neither WT nor mCV-N expressing $L$. jensenii induced a significant upregulation or down regulation of any of these mediators with the exception of ICAM-1 which was increased in WT-colonized vaginal cells in the first $48 \mathrm{~h}$ only $(p<0.05)$ (Figure 7d). In contrast, MALP-2 induced a weak upregulation of IL-1 $\beta(p<0.05)$ (Figure $7 \mathrm{a})$, no change in IL-1RA (Figure 7b) but a robust (several-fold) upregulation $(p<0.001)$ of IL-6, ICAM-1, MIP-3 $\alpha$ and RANTES (Figure $7 \mathrm{c}-\mathrm{f}$ ), and the chemokines remained increased for $48 \mathrm{~h}$ after MALP-2 removal (Figure 7e and $\mathrm{f}$ ).

\section{Expression of functional mCV-N expression and anti-HIV activity is preserved in epithelia-associated $L$. jensenii strains}

Filtered sterile supernatants from $24 \mathrm{~h} L$. jensenii colonized vaginal and endocervical cells were assessed for mCV-N recovery with western blot analysis on an SDSPAGE gel probed with anti-CV-N antibodies. All mCV$\mathrm{N}$ expressing strains (lanes 2-4; Figure 8a, lanes 4-5;
NF- $\kappa B$ activation, we exposed the vaginal epithelial cells to wild type and bioengineered bacterial strains and MALP-2 and maintained the cultures for three days with supernatants harvested for protein measurement and replaced with plain KSFM medium at each $24 \mathrm{~h}$ interval. At the end of each $24 \mathrm{~h}$ time period epithelial cells were lysed for assessment of epithelia-associated CFU. No significant variation in CFU was observed in multiple 


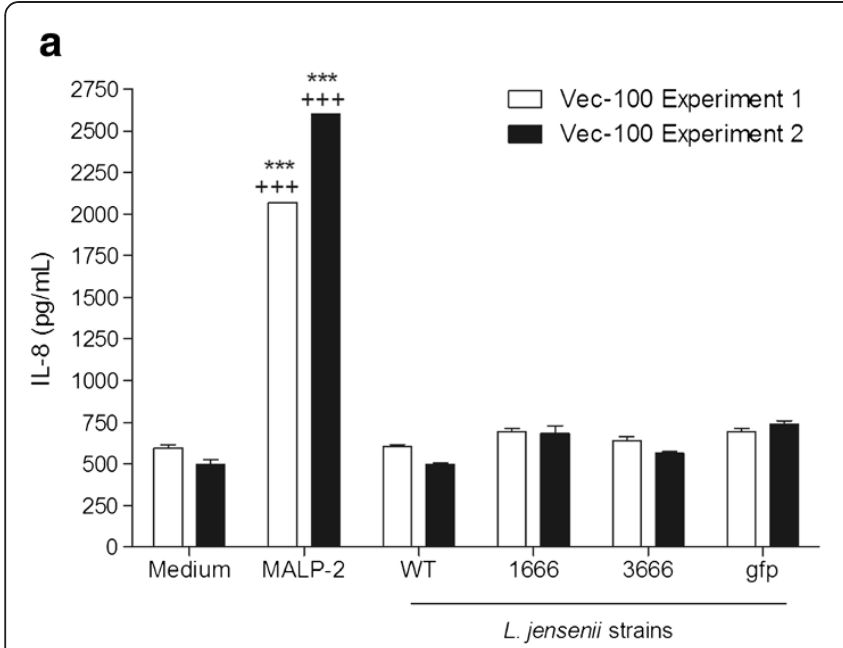

b

Figure 4 Cytokine profiles induced by bacteria or synthetic TLR2/6 ligand in cervicovaginal colonized epithelial model. Similar IL-8 levels measured in supernatants derived from primary and immortalized epithelial cells cultured with L. jensenii 1153-1666, 3666, gfp bioengineered and L. jensenii 1153 wild type (WT) strains or MALP-2 $50 \mathrm{nM}$ as a positive control. (Figure 4a) Two independent experiments with (VEC-100 ${ }^{\mathrm{TM}}$ ) primary ectocervical originated tissue. (Figure 4b) Vaginal (Vk2/E6E7) and endocervical (End1/E6E7) epithelial colonized cells in one representative of three experiments. Bars represent mean and SEM from duplicate cultures. ${ }^{* * *} P<0.001$ different from medium control, ${ }^{+++} P<0.001$ different from L. jensenii WT.

Figure $8 \mathrm{~b}$ ) produced full length $\mathrm{mCV}-\mathrm{N}$ as compared to a mCV-N standard (lane 1; Figure 8b). As expected, no background binding to $\mathrm{mCV}-\mathrm{N}$ was detected in cell culture supernatants derived from the MALP-2 or medium controls (lanes 6-7; Figure 8a) or from either the WT (lane 1; Figure 8a, lane 2; Figure $8 \mathrm{~b}$ ) or $\beta$-glucuronidase producing strains (lane 5; Figure 8a, lane 6; Figure $8 \mathrm{~b}$ ). No protein loss to filtration was observed when $1 \mu \mathrm{g}$ of $\mathrm{mCV}-\mathrm{N}$ standard was spiked in $1 \mathrm{ml}$ of medium and probed with anti-mCV-N antibody in a western blot pre and post-filtration (Figure 8c).

Gp120 binding activity was measured in $24 \mathrm{~h}$ filtered sterile supernatants from $L$. jensenii colonized cervical and vaginal epithelial cells. Only the $\mathrm{mCV}-\mathrm{N}$ producing strain resulted in gp120 binding activity compared to the WT and $\beta$-glucuronidase producing strains, MALP-2 or medium control (Figure 8d). Data were replicated in multiple experiments not shown here.

\section{Discussion}

Vaginal probiotics or live biotherapeutic products as defined by the FDA [39] may reduce the risk of HIV transmission by: expressing antiviral factors, restoring the normal microbiota, inhibiting bacterial pathogens and modulating immuno-inflammatory responses without compromising the homeostatic environment of the host. Lactobacilli are commensal Gram-positive bacteria that widely populate the healthy female vaginal mucosa [21,22,40,41]. Several Lactobacillus strains have been implicated by epidemiologic and/or experimental evidence in the maintenance of a homeostatic infection- free microenvironment most notably due to the impact of the bacteria's lactic acid and $\mathrm{H}_{2} \mathrm{O}_{2}$ production in generating an adverse environment for HIV and other STDs. $[21,40,42-44]$. These properties may contribute to the reduction of viral particles at the site of infection $[13,45]$. In contrast, a reduction in the number of Lactobacillus in the vaginal microbiota has been associated with the acquisition of bacterial vaginosis (BV) [42,45-47]. The presence of BV is correlated with an increased risk of acquiring herpes simplex virus type 2 [48], HIV and other STDs $[46,49]$. In turn, co-infection with sexually transmitted pathogens is associated with an increased risk of acquiring and transmitting HIV [50,51]. Naturally occurring lactobacilli demonstrate an inverse relationship with HIV infectivity [44,45]. Sha et al. found an inverse ratio between indigenous Lactobacillus counts and HIV RNA detected in cervical vaginal lavage at nearly significant levels [46]. In another study, $L$. jensenii demonstrated a reduction in HIV infection by $23 \%$ in-vitro [26].

Our finding that $L$. jensenii can induce NF-kB activation and at the same time maintain low levels of inflammation-associated proteins has important implications for its potential use as a vaginal probiotic or biotherapeutic. NF- $\mathrm{kB}$ is a major transcription factor that plays a key role in inflammatory disease and upregulates a myriad of inflammation-associated genes including those studied here [52]. At the same time NF-кB participates in its own negative feedback loop promoting the resolution of inflammation in-vivo [53]. Thus, the net effect of NF- $\mathrm{kB}$ activation depends on the cell and tissue context, the interplay of a number of intra- and 


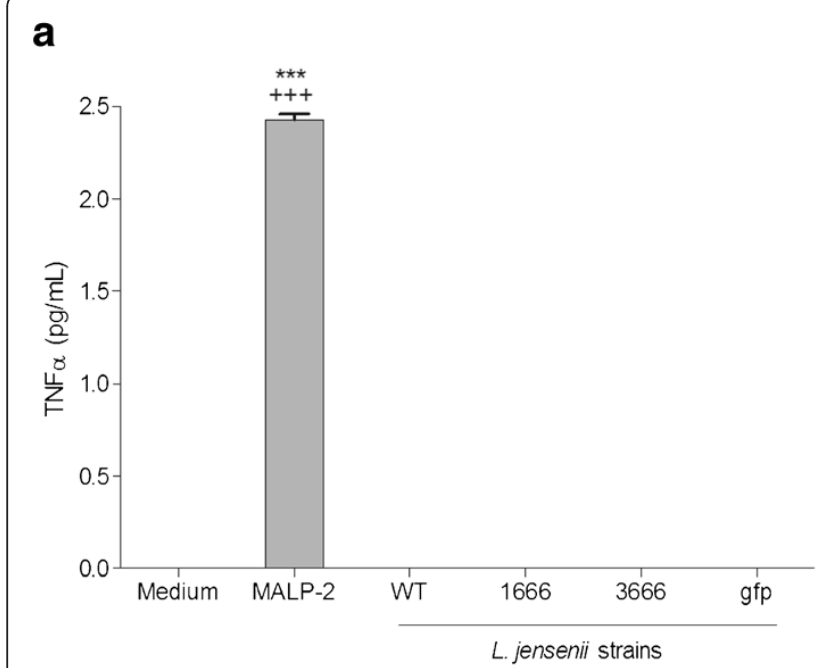

C

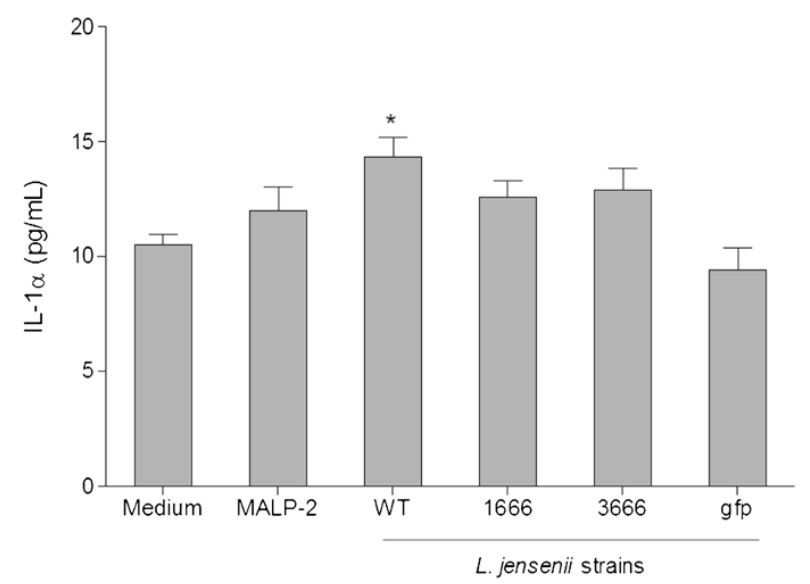

b

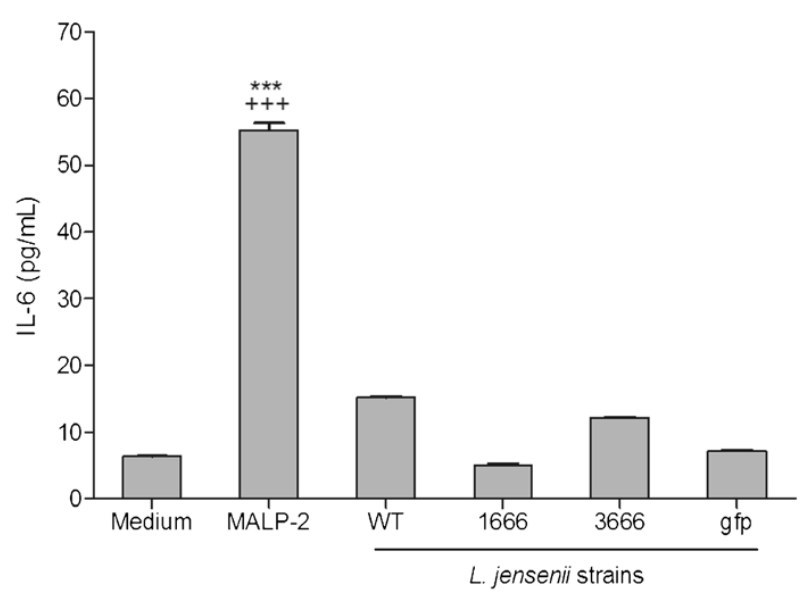

d

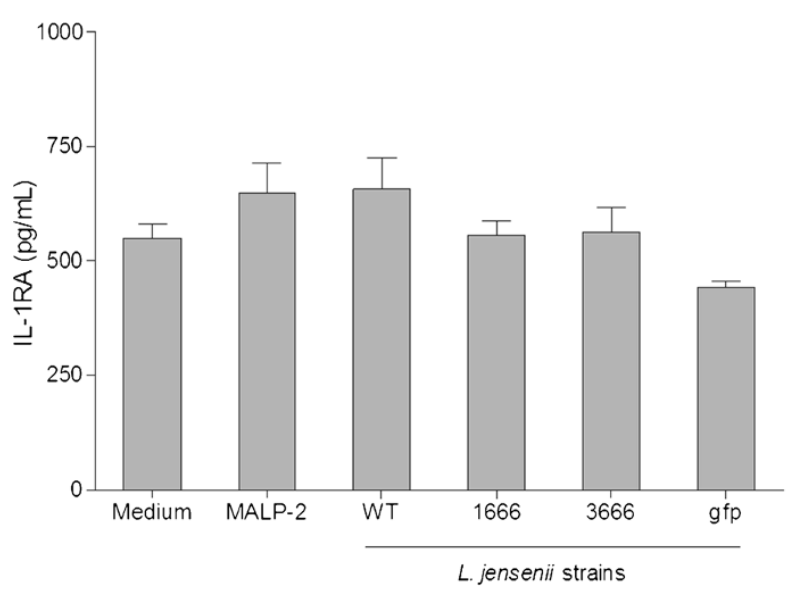

Figure 5 Absence of a pro-inflammatory cytokine response in $L$. jensenii colonized epithelial model. (Figure 5a) TNF-a, (Figure 5b) IL-6, (Figure 5c) IL-1a, (Figure 5d) IL-1RA cytokine levels measured in supernatants from vaginal (Vk2/E6E7) epithelium cultured for $24 \mathrm{~h}$ with $\mathrm{L}$. jensenii 1153-1666, 3666, and gfp bioengineered strains and L. jensenii 1153 wild (WT) strain or MALP-2 (50 nM) as a positive control. Bars represent mean and SEM from duplicate and triplicate cultures in two independent experiments. ${ }^{* *} P<0.001,{ }^{*} P<0.05$ different from medium control, ${ }^{+++} P<0.001$ different from L. jensenii 1153 WT.

extra-cellular factors, and the nature of the activating signal. It has been previously shown that some lactobacillus species (L. crispatus and L. acidophilus) can cause NF- $\mathrm{KB}$ activation and yet maintain low levels of IL-8 and RANTES [20]. Another study showed that L. jensenii can suppress IL- 8 induced by TLR ligands [54]. Interestingly, a non-vaginal lactobacillus species (L. kefiranofaciens) induced production of MIP-3 $\alpha$ [55] and other vaginal bacteria, associated with bacterial vaginosis e.g. $P$. bivia and $A$. vaginae induced simultaneous NF- $\mathrm{kB}$ activation and upregulation of inflammatory proteins in contrast to vaginal L. crispatus and L. acidophilus, which maintained low levels of proinflammatory proteins in the vaginal colonization context [20]. We now demonstrate for the first time using an expanded panel of innate immunity mediators that this immuno-modulatory phenomenon is also true for the L. jensenii isolate 1153 and its bioengineered derivatives. The results of our study agree with clinical observations showing an association of vaginal lactobacilli with relatively low levels of proinflammatory mediators in-vivo [56-58]. Furthermore, the results from our in-vitro model are in agreement with findings generated in a macaque model of SHIV infection [26]. Vaginal levels of IL-6, IL-8, IL-1 $\beta$ and IL-1RA were not different between macaques with no lactobacilli, those colonized with lactobacillus indigenous for the macaque and those colonized with $\mathrm{mCV}-\mathrm{N}$ expressing $L$. jensenii 1153-1666 [26]. Other commensal bacteria have also been shown to downregulate inflammatory responses. For example, $H$. pylori downregulated IL-8, MIP-3 $\alpha$ and other 

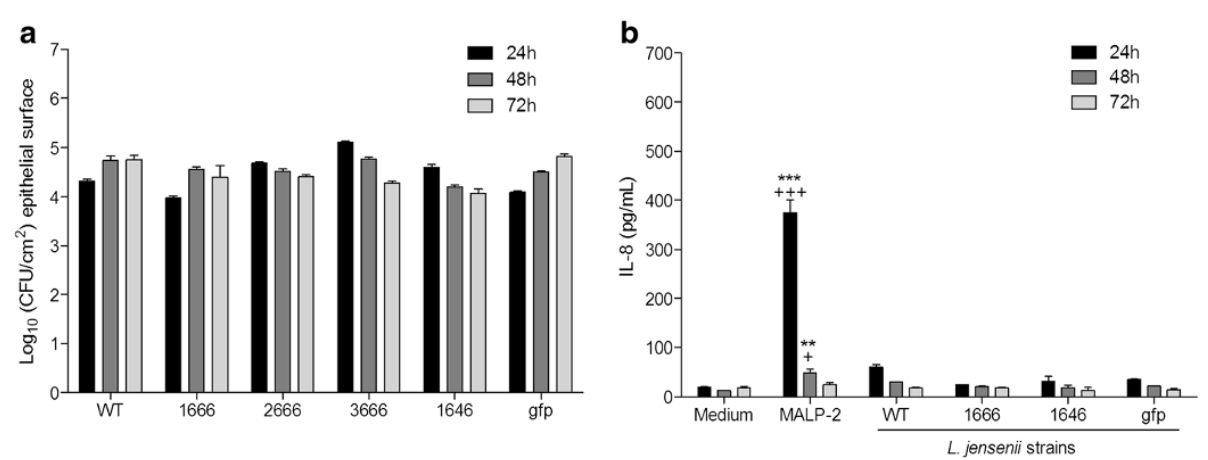

Figure 6 L. jensenii consistently colonize epithelial model over a $72 \mathrm{~h}$ time period in the absence of IL-8 upregulation. Vaginal epithelial colonization of L. jensenii 1153-1666, 2666, 3666, 1646 and gfp bioengineered strains compared with L. jensenii 1153 wild type (WT) strain at the end of $24 \mathrm{~h}, 48 \mathrm{~h}$, and $72 \mathrm{~h}$, time points. (Figure 6a) Colony forming units (CFU) enumerated from lysates harvested at the end of each $24 \mathrm{~h}$ incubation time period. (Figure $6 \mathrm{~b}$ ) Consistent IL-8 profile maintained over time measured in the corresponding supernatants collected at the end of each $24 \mathrm{~h}$ incubation. Bars represent mean and SEM from duplicate cultures in four independent experiments. ${ }^{* *} P<0.001,{ }^{* *} P<0.001$ different from medium control, ${ }^{++} P<0.001,{ }^{+} P<0.001$ different from $L$. jensenii WT.

chemokines through inducing microRNA expression in host epithelial cells [59]. Further research is required to determine the molecular mechanisms, by which vaginal $L$. jensenii, L. crispatus and L. acidohilus tune the host innate immune responses to avoid proinflammatory protein production in the presence of a potent NF-kB activation.

The innate immunity mediators assessed here (TNF- $\alpha$, IL-1 $\alpha$, IL-1RA, IL-6, ICAM-1, IL-8, RANTES, MIP-3 $\alpha$ and SLPI) are known as indicators of mucosal toxicity, and inflammation and have been used and recommended for microbicide safety evaluation $[32,35,60]$. In contrast to IL-1RA, which displays anti-inflammatory properties [35,61], the pro-inflammatory cytokines IL- $1 \alpha$, TNF- $\alpha$, IL- 6 and IL- 8 can activate HIV viral replication in infected cells [62-66]. Similarly vaginal inflammation increases the risk of HIV transmission by increasing the number of host cells at the site of infection $[35,67,68]$. IL-8 is also involved in the recruitment of innate immune cells, neutrophils and CD4 positive T-cells to the site of infection [32,64,69]. MIP-3 $\alpha$ is a chemokine recruiting dendritic cells and along with RANTES, a chemokine for $\mathrm{T}$ cells, is known to play a role in the early recruitment of HIV target cells [70,71]. Thus, the lack of upregulation of these proinflammatory mediators by the cervicovaginal epithelial cells is a desired safety feature of the mCV-N expressing $L$. jensenii strain. Concerns about the safety of CV-N in the absence of lactobacillus have been raised by Huskens et al. [72] showing that administration of $\mathrm{CV}-\mathrm{N}$ to pre-stimulated PBMC induced proinflammatory cytokine upregulation and it also had in-vitro mitogenic activity. It is important to clarify that the study by Huskens et al. is of limited relevance to the clinical application of the $\mathrm{mCV}-\mathrm{N}$-expressing lactobacilli for several reasons: 1 ) the $\mathrm{mCV}-\mathrm{N}$ is a genetically modified stable monomeric derivative of the natural cyanobacterium-produced $\mathrm{CV}-\mathrm{N}$ protein referred to in that older study, 2) Huskens et al. seemed to have used E. coli expressed CV-N protein; however, they don't address steps taken to eliminate or control for endotoxin contamination in their experiments. In contrast, in our study $\mathrm{mCV}-\mathrm{N}$ is expressed in the context of lactobacillus which lacks endotoxin.

IL-1 $\alpha$, IL-1RA and SLPI are stored in the epithelial cell and released upon membrane damage $[35,61,73]$. The fact that none of the $L$. jensenii strains caused significant increase in these mediators suggests preserved membrane integrity in addition to lack of immunotoxicity. A decrease in SLPI levels is also often associated with an increased risk of HIV infection [74,75]. This in addition to the lack of apoptosis assessed by caspase- 3 levels suggests that $L$. jensenii is capable of colonizing and selfsustaining the human vaginal epithelia without cellular toxicity. In this model $L$. jensenii produced full-length biologically active $\mathrm{mCV}-\mathrm{N}$ within the epithelial context. $\mathrm{mCV}-\mathrm{N}$ did not compromise cell viability or elicit an immuno-inflammatory response when tested in both rabbits and macaques [23,76].

This study confirmed the ability of bioengineered $L$. jensenii strains to reproducibly colonize the cervicovaginal epithelial model and to maintain anti-HIV expression of functional peptides in-vitro without the induction of a significant change in inflammation associated proteins. The ability for endogenous lactobacilli to colonize and establish dominance in the vaginal microenvironment has been previously investigated. Lactobacillus isolates were successfully introduced intravaginally as a probiotic against BV and urinary tract infections in women [77,78]. In a study conducted by Hemmerling et al. L. crispatus colonized BV infected women $61-78 \%$ of the time [79]. We found all $L$. jensenii strains including the mCV-N 


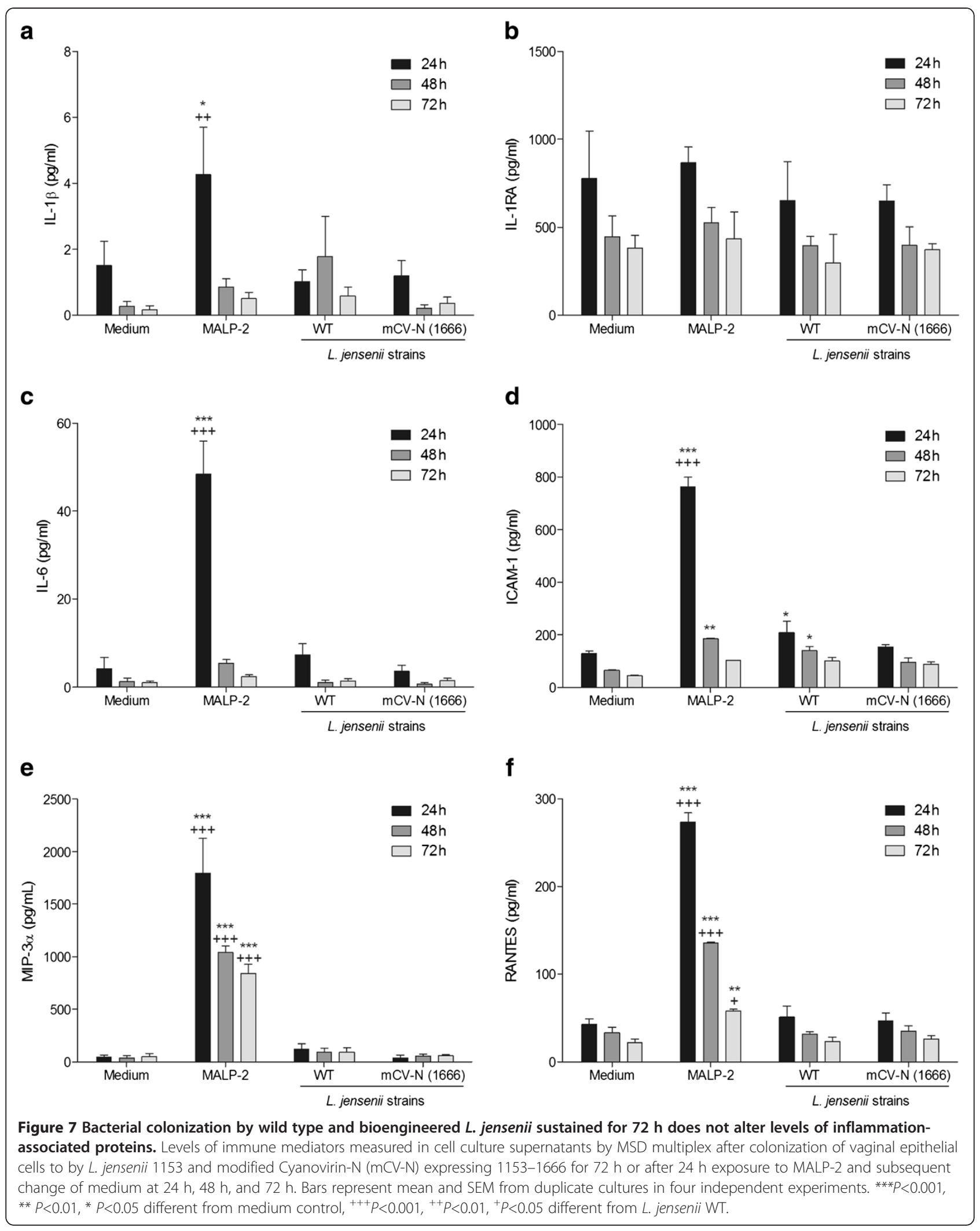




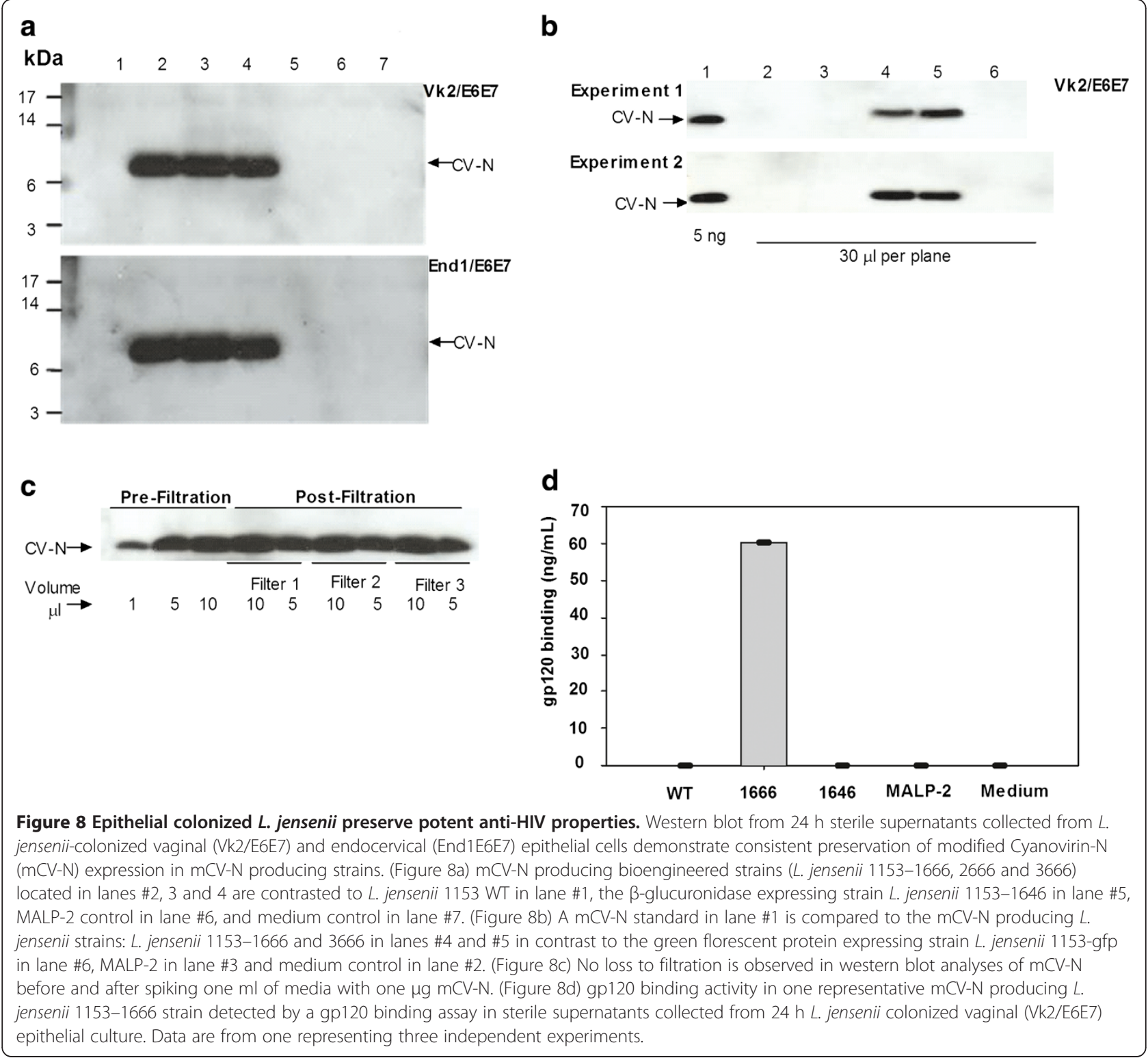

expressing L. jensenii (1153-1666) capable of reproducibly and stably colonizing the human cervicovaginal epithelial cells over a $72 \mathrm{~h}$ period without significant perturbations to innate immune barrier parameters while abundantly expressing $\mathrm{mCV}-\mathrm{N}$ detectable by both Western blot and the functional gp120 assay. The stable colonization $\mathrm{mCV}-\mathrm{N}$ expressing $L$. jensenii $1153-1666$ strain and the stability and anti-HIV activity of the $\mathrm{mCV}-\mathrm{N}$ protein have been confirmed in a mouse model over a period of six days [15] and in the Rhesus macaque for six weeks post inoculation [26], where it reduced SHIV infection by $63 \%$ in a repeated challenge model, without altering markers associated with mucosal barrier function. Taken together these in-vivo findings provide validation of our in-vitro model.
The bioengineered mCV-N, similarly to the natural protein, is stable at a broad $\mathrm{pH}$ range from 4-8.2 [15,23]. This wide $\mathrm{pH}$ stability spectrum encompasses both the acidic $\mathrm{pH}$ generated by lactic acid producing bacteria and the slightly more alkaline $\mathrm{pH}$ introduced to the vaginal environment with seminal fluid. The natural and modified $\mathrm{CV}-\mathrm{N}$ molecules are also resistant to thermal and chemical denaturation, which would allow it to be produced and stored in a variety of environmental conditions $[15,23]$. These attributes render $\mathrm{mCV}-\mathrm{N}$ to be a promising microbicide candidate.

In this proof-of-concept in-vitro model, the bioengineered $L$. jensenii did not differ from the wild type parental strain in term of epithelial colonization capacity and did not induce a pro-inflammatory profile in the 
human epithelial cell context. Thus, our in-vitro findings along with in-vivo studies performed in the murine and macaque model pave the way to further clinical safety evaluations necessary to confirm the effects these bacteria would have when introduced into the human cervicovaginal environment and how it would affect other endogenous microbiota in-vivo. There are many components that are unique to the human vaginal environment and therefore would be best investigated in-vivo i.e. indigenous bacterial biofilms, $\mathrm{pH}$, mucosal immunoglobulins and hormones, and vaginal practices that may modify the effects of both the bioengineered bacteria and the activity of $\mathrm{mCV}-\mathrm{N}$ peptide.

\section{Conclusion}

Our in-vitro human vaginal colonization model produced consistent results, validated by their agreement with findings from the in-vivo macaque model. Because of its reproducibility and low cost, the in-vitro colonization model can be used for high throughput preclinical screening and side-by-side comparison of multiple bacterial strains, bioengineered derivatives and probiotic candidates to select those with best homeostatic properties. In support of our hypothesis, we were able to compare microbiotaepithelial interactions of multiple $L$. jensenii WT and bioengineered strains in a reproducible manner. The bioengineered $L$. jensenii derivatives were able to deliver a bioactive anti-HIV peptide without inducing cellular toxicity or alterations in levels of pro-inflammatory cytokines and protective mucosal immune mediators e.g. SLPI or IL-1RA. Our pre-clinical safety data in combination with the results from the macaque model provide support for future clinical evaluations of the bioengineered $L$. jensenii bacteria as an anti-HIV microbicide.

\section{Competing interests}

QX was previously employed by Osel, Mountain View, CA, the company that has provided the bioengineered strains for this study.

\section{Authors' contributions \\ HSY wrote the manuscript, ran the immunoassays and conducted the experiments along with RNF. RNF was responsible for the direction of the study, experimental design and data integrity. QX provided all bacterial strains and bioengineered derivatives, directed the western blot and gp120 binding assays, reviewed the progress and manuscript, and provided comments. All authors read and approved the final manuscript.}

\footnotetext{
Acknowledgments

The authors thank Y. Liu, L. Jia and X. Liu for performing the western blot and gp-120 assay. This work was supported by grant NIH-NIAID, 2R21Al071978 to Osel Inc (XQ) and subcontract to Brigham and Women's Hospital (RNF). The development of the vaginal colonization model was first supported by a Connor's Seed Grant for Gender Biology, Center for Women's Health, Brigham and Women's Hospital (RNF), NICHD R21HD054451 (RNF) and R01Al079085 (RNF).

\section{Author details}

'Laboratory of Genital Tract Biology, Department of Obstetrics, Gynecology and Reproductive Biology, Brigham and Women's Hospital, Harvard Medical
}

School, 221 Longwood AvenueBoston, MA, USA. ${ }^{2}$ Osel, 320 Logue Avenue, Mountain View, CA, USA.

Received: 31 July 2012 Accepted: 26 December 2012

Published: 8 January 2013

\section{References}

1. UNAIDS World Day Report 2011.:; [http://www.unaids.org/en/media/unaids/ contentassets/documents/unaidspublication/2011/ JC2216_WorldAIDSday_report_2011_en.pdf].

2. Van Damme L, Govinden R, Mirembe FM, Guedou F, Solomon S, Becker ML, Pradeep BS, Krishnan AK, Alary M, Pande B, et al: Lack of effectiveness of cellulose sulfate gel for the prevention of vaginal HIV transmission. $N$ Engl J Med 2008, 359(5):463-472.

3. Skoler-Karpoff S, Ramjee G, Ahmed K, Altini L, Plagianos MG, Friedland B, Govender S, De Kock A, Cassim N, Palanee T, et al: Efficacy of Carraguard for prevention of HIV infection in women in South Africa: a randomised, double-blind, placebo-controlled trial. Lancet 2008, 372(9654):1977-1987.

4. Van Damme L, Ramjee G, Alary M, Vuylsteke B, Chandeying V, Rees H, Sirivongrangson P, Mukenge-Tshibaka L, Ettiegne-Traore V, Uaheowitchai C, et al: Effectiveness of COL-1492, a nonoxynol-9 vaginal gel, on HIV-1 transmission in female sex workers: a randomised controlled trial. Lancet 2002, 360(9338):971-977.

5. Feldblum PJ, Adeiga A, Bakare R, Wevill S, Lendvay A, Obadaki F, Olayemi MO, Wang L, Nanda K, Rountree W: SAVVY vaginal gel (C31G) for prevention of HIV infection: a randomized controlled trial in Nigeria. PLoS One 2008, 3(1):e1474.

6. McCormack S, Ramjee G, Kamali A, Rees H, Crook AM, Gafos M, Jentsch U, Pool R, Chisembele M, Kapiga S, et al: PRO2000 vaginal gel for prevention of HIV-1 infection (Microbicides Development Programme 301): a phase 3, randomised, double-blind, parallel-group trial. Lancet 2010, 376(9749):1329-1337.

7. Abdool Karim Q, Abdool Karim SS, Frohlich JA, Grobler AC, Baxter C, Mansoor LE, Kharsany AB, Sibeko S, Mlisana KP, Omar Z, et al: Effectiveness and safety of tenofovir gel, an antiretroviral microbicide, for the prevention of HIV infection in women. Science 2010, 329(5996):1168-1174.

8. MTN Statement on Decision to Discontinue Use of Tenofovir Gel in VOICE, a Major HIV Prevention Study in Women. [http://www.mtnstopshiv.org/node/ 3909].

9. Hillier SL, Moench T, Shattock R, Black R, Reichelderfer P, Veronese F: In vitro and in vivo: the story of nonoxynol 9. J Acquir Immune Defic Syndr 2005, 39(1):1-8.

10. Klasse PJ, Shattock RJ, Moore JP: Which topical microbicides for blocking HIV-1 transmission will work in the real world? PLOS Med 2006, 3(9):e351.

11. Hendrix CW, Cao YJ, Fuchs EJ: Topical microbicides to prevent HIV: clinical drug development challenges. Annu Rev Pharmacol Toxicol 2009, 49:349-375.

12. Fichorova RN: Guiding the vaginal microbicide trials with biomarkers of inflammation. J Acquir Immune Defic Syndr 2004, 37(Suppl 3):S184-S193.

13. Chang TL, Chang CH, Simpson DA, Xu Q, Martin PK, Lagenaur LA, Schoolnik GK, Ho DD, Hillier SL, Holodniy M, et al: Inhibition of HIV infectivity by a natural human isolate of Lactobacillus jensenii engineered to express functional two-domain CD4. Proc Natl Acad Sci USA 2003, 100(20):11672-11677.

14. Giomarelli B, Provvedi R, Meacci F, Maggi T, Medaglini D, Pozzi G, Mori T, McMahon JB, Gardella R, Boyd MR: The microbicide cyanovirin-N expressed on the surface of commensal bacterium Streptococcus gordonii captures HIV-1. AIDS 2002, 16(10):1351-1356.

15. Liu $X$, Lagenaur LA, Simpson DA, Essenmacher KP, Frazier-Parker CL, Liu $Y$, Tsai D, Rao SS, Hamer DH, Parks TP, et al: Engineered vaginal lactobacillus strain for mucosal delivery of the human immunodeficiency virus inhibitor cyanovirin-N. Antimicrob Agents Chemother 2006, 50(10):3250-3259.

16. Pusch O, Boden D, Hannify S, Lee F, Tucker LD, Boyd MR, Wells JM, Ramratnam B: Bioengineering lactic acid bacteria to secrete the HIV-1 virucide cyanovirin. J Acquir Immune Defic Syndr 2005, 40(5):512-520.

17. Pusch O, Kalyanaraman R, Tucker LD, Wells JM, Ramratnam B, Boden D: An anti-HIV microbicide engineered in commensal bacteria: secretion of HIV-1 fusion inhibitors by lactobacilli. AIDS 2006, 20(15):1917-1922. 
18. Vangelista L, Secchi M, Liu X, Bachi A, Jia L, Xu Q, Lusso P: Engineering of Lactobacillus jensenii to secrete RANTES and a CCR5 antagonist analogue as live HIV-1 blockers. Antimicrob Agents Chemother 2010, 54(7):2994-3001.

19. Chancey CJ, Khanna KV, Seegers JF, Zhang GW, Hildreth J, Langan A, Markham RB: Lactobacilli-expressed single-chain variable fragment (scFv) specific for intercellular adhesion molecule 1 (ICAM-1) blocks cellassociated HIV-1 transmission across a cervical epithelial monolayer. J Immunol 2006, 176(9):5627-5636.

20. Fichorova RN, Yamamoto H, Delaney ML, Onderdonk AB, Doncel GF: A novel vaginal microflora colonization model provides new insight into microbicide mechanism of action. MBio 2011, 2(6):e00168-00111.

21. Antonio MA, Hawes SE, Hillier SL: The identification of vaginal Lactobacillus species and the demographic and microbiologic characteristics of women colonized by these species. J Infect Dis 1999, 180(6):1950-1956.

22. Zhou X, Bent SJ, Schneider MG, Davis CC, Islam MR, Forney LJ Characterization of vaginal microbial communities in adult healthy women using cultivation-independent methods. Microbiology 2004, 150(Pt 8):2565-2573.

23. Boyd MR, Gustafson KR, McMahon JB, Shoemaker RH, O'Keefe BR, Mori T, Gulakowski RJ, Wu L, Rivera MI, Laurencot CM, et al: Discovery of cyanovirin- $\mathrm{N}$, a novel human immunodeficiency virus-inactivating protein that binds viral surface envelope glycoprotein gp120: potential applications to microbicide development. Antimicrob Agents Chemother 1997, 41(7):1521-1530.

24. Dey B, Lerner DL, Lusso P, Boyd MR, Elder JH, Berger EA: Multiple antiviral activities of cyanovirin-N: blocking of human immunodeficiency virus type 1 gp120 interaction with CD4 and coreceptor and inhibition of diverse enveloped viruses. J Virol 2000, 74(10):4562-4569.

25. Boskey ER, Telsch KM, Whaley KJ, Moench TR, Cone RA: Acid production by vaginal flora in vitro is consistent with the rate and extent of vaginal acidification. Infect Immun 1999, 67(10):5170-5175

26. Lagenaur LA, Sanders-Beer BE, Brichacek B, Pal R, Liu X, Liu Y, Yu R, Venzon D, Lee PP, Hamer DH: Prevention of vaginal SHIV transmission in macaques by a live recombinant Lactobacillus. Mucosal Immunol 2011, 4(6):648-657.

27. Trifonova RT, Doncel GF, Fichorova RN: Polyanionic microbicides modify Toll-like receptor-mediated cervicovaginal immune responses. Antimicrob Agents Chemother 2009, 53(4):1490-1500.

28. Nishi K, Schnier JB, Bradbury ME: Cell shape change precedes staurosporine-induced stabilization and accumulation of p27kip1. Exp Cell Res 2002, 280(2):233-243.

29. Windham TC, Parikh NU, Siwak DR, Summy JM, McConkey DJ, Kraker AJ, Gallick GE: Src activation regulates anoikis in human colon tumor cell lines. Oncogene 2002, 21(51):7797-7807.

30. Fichorova RN, Rheinwald JG, Anderson DJ: Generation of papillomavirusimmortalized cell lines from normal human ectocervical, endocervical, and vaginal epithelium that maintain expression of tissue-specific differentiation proteins. Biol Reprod 1997, 57(4):847-855.

31. Fichorova RN, Anderson DJ: Differential expression of immunobiological mediators by immortalized human cervical and vaginal epithelial cells. Biol Reprod 1999, 60(2):508-514.

32. Fichorova RN, Bajpai M, Chandra N, Hsiu JG, Spangler M, Ratnam V, Doncel GF: Interleukin (IL)-1, IL-6, and IL-8 predict mucosal toxicity of vaginal microbicidal contraceptives. Biol Reprod 2004, 71(3):761-769.

33. Fichorova RN, Cronin AO, Lien E, Anderson DJ, Ingalls RR: Response to Neisseria gonorrhoeae by cervicovaginal epithelial cells occurs in the absence of toll-like receptor 4-mediated signaling. J Immunol 2002, 168(5):2424-2432

34. Fichorova RN, Trifonova RT, Gilbert RO, Costello CE, Hayes GR, Lucas J, Singh BN: Trichomonas vaginalis lipophosphoglycan triggers a selective upregulation of cytokines by human female reproductive tract epithelial cells. Infect Immun 2006, 74(10):5773-5779.

35. Fichorova RN, Tucker LD, Anderson DJ: The molecular basis of nonoxynol-9induced vaginal inflammation and its possible relevance to human immunodeficiency virus type 1 transmission. J Infect Dis 2001, 184(4):418-428.

36. Fichorova RN, Zhou F, Ratnam V, Atanassova V, Jiang S, Strick N, Neurath AR: Anti-human immunodeficiency virus type 1 microbicide cellulose acetate 1,2-benzenedicarboxylate in a human in vitro model of vaginal inflammation. Antimicrob Agents Chemother 2005, 49(1):323-335.

37. Canny GO, Trifonova RT, Kindelberger DW, Colgan SP, Fichorova RN: Expression and function of bactericidal/permeability-increasing protein in human genital tract epithelial cells. J Infect Dis 2006, 194(4):498-502.
38. Trifonova RT, Pasicznyk JM, Fichorova RN: Biocompatibility of solid-dosage forms of anti-human immunodeficiency virus type 1 microbicides with the human cervicovaginal mucosa modeled ex vivo. Antimicrob Agents Chemother 2006, 50(12):4005-4010.

39. FDA: In Guidance for Industry: Early Clinical Trials With Live Biotherapeutic Products: Chemistry, Manufacturing, and Control Information; Availability. Edited by Administration FD: Federal Register; 2012:9947.

40. Redondo-Lopez V, Cook RL, Sobel JD: Emerging role of lactobacilli in the control and maintenance of the vaginal bacterial microflora. Rev Infect Dis 1990, 12(5):856-872.

41. Vasquez A, Jakobsson T, Ahrne S, Forsum U, Molin G: Vaginal lactobacillus flora of healthy Swedish women. J Clin Microbiol 2002, 40(8):2746-2749.

42. Hawes SE, Hillier SL, Benedetti J, Stevens CE, Koutsky LA, Wolner-Hanssen P, Holmes KK: Hydrogen peroxide-producing lactobacilli and acquisition of vaginal infections. J Infect Dis 1996, 174(5):1058-1063.

43. Zheng HY, Alcorn TM, Cohen MS: Effects of H2O2-producing lactobacilli on Neisseria gonorrhoeae growth and catalase activity. J Infect Dis 1994 170(5):1209-1215.

44. Klebanoff SJ, Coombs RW: Viricidal effect of Lactobacillus acidophilus on human immunodeficiency virus type 1: possible role in heterosexual transmission. J Exp Med 1991, 174(1):289-292.

45. Martin HL, Richardson BA, Nyange PM, Lavreys L, Hillier SL, Chohan B, Mandaliya K, Ndinya-Achola JO, Bwayo J, Kreiss J: Vaginal lactobacilli, microbial flora, and risk of human immunodeficiency virus type 1 and sexually transmitted disease acquisition. J Infect Dis 1999, 180(6):1863-1868,

46. Sha BE, Zariffard MR, Wang QJ, Chen HY, Bremer J, Cohen MH, Spear GT: Female genital-tract HIV load correlates inversely with Lactobacillus species but positively with bacterial vaginosis and Mycoplasma hominis. $J$ Infect Dis 2005, 191(1):25-32.

47. Cu-Uvin S, Hogan JW, Caliendo AM, Harwell J, Mayer KH, Carpenter CC: Association between bacterial vaginosis and expression of human immunodeficiency virus type 1 RNA in the female genital tract. Clin Infect Dis 2001, 33(6):894-896.

48. Cherpes TL, Melan MA, Kant JA, Cosentino LA, Meyn LA, Hillier SL: Genital tract shedding of herpes simplex virus type 2 in women: effects of hormonal contraception, bacterial vaginosis, and vaginal group $B$ Streptococcus colonization. Clin Infect Dis 2005, 40(10):1422-1428.

49. Taha TE, Hoover DR, Dallabetta GA, Kumwenda NI, Mtimavalye LA, Yang LP, Liomba GN, Broadhead RL, Chiphangwi JD, Miotti PG: Bacterial vaginosis and disturbances of vaginal flora: association with increased acquisition of HIV. AIDS 1998, 12(13):1699-1706.

50. Wasserheit JN: Epidemiological synergy. Interrelationships between human immunodeficiency virus infection and other sexually transmitted diseases. Sex Transm Dis 1992, 19(2):61-77.

51. Padian NS, Shiboski SC, Glass SO, Vittinghoff E: Heterosexual transmission of human immunodeficiency virus (HIV) in northern California: results from a ten-year study. Am J Epidemiol 1997, 146(4):350-357.

52. Tak PP, Firestein GS: NF-kappaB: a key role in inflammatory diseases. J Clin Invest 2001, 107(1):7-11.

53. Lawrence T, Gilroy DW, Colville-Nash PR, Willoughby DA: Possible new role for NF-kappaB in the resolution of inflammation. Nat Med 2001, 7(12):1291-1297.

54. Rose WA 2nd, McGowin CL, Spagnuolo RA, Eaves-Pyles TD, Popov VL, Pyles RB: Commensal bacteria modulate innate immune responses of vaginal epithelial cell multilayer cultures. PLoS One 2012, 7(3):e32728.

55. Chen YP, Hsiao PJ, Hong WS, Dai TY, Chen MJ: Lactobacillus kefiranofaciens M1 isolated from milk kefir grains ameliorates experimental colitis in vitro and in vivo. J Dairy Sci 2011, 95(1):63-74.

56. Spear GT, Zariffard MR, Cohen MH, Sha BE: Vaginal IL-8 levels are positively associated with Candida albicans and inversely with lactobacilli in HIVinfected women. J Reprod Immunol 2008, 78(1):76-79.

57. Fichorova RN, Onderdonk AB, Yamamoto H, Delaney ML, DuBois AM, Allred E, Leviton A: Maternal microbe-specific modulation of inflammatory response in extremely low-gestational-age newborns. MBio 2011, 2(1):e00280-00210.

58. Witkin SS, Linhares IM, Giraldo P: Bacterial flora of the female genital tract: function and immune regulation. Best Pract Res Clin Obstet Gynaecol 2007, 21(3):347-354

59. Liu Z, Xiao B, Tang B, Li B, Li N, Zhu E, Guo G, Gu J, Zhuang Y, Liu X, et al: Up-regulated microRNA-146a negatively modulate Helicobacter 
pylori-induced inflammatory response in human gastric epithelial cells. Microbes and infection / Institut Pasteur 2010, 12(11):854-863.

60. Mauck CK, Ballagh SA, Creinin MD, Weiner DH, Doncel GF, Fichorova RN, Schwartz JL, Chandra N, Callahan MM: Six-day randomized safety trial of intravaginal lime juice. J Acquir Immune Defic Syndr 2008, 49(3):243-250.

61. Arend WP: The balance between IL-1 and IL-1Ra in disease. Cytokine Growth Factor Rev 2002, 13(4-5):323-340.

62. Poli G, Kinter A, Justement JS, Kehrl JH, Bressler P, Stanley S, Fauci AS: Tumor necrosis factor alpha functions in an autocrine manner in the induction of human immunodeficiency virus expression. Proc Natl Acad Sci USA 1990, 87(2):782-785.

63. Poli G, Kinter AL, Fauci AS: Interleukin 1 induces expression of the human immunodeficiency virus alone and in synergy with interleukin 6 in chronically infected $\mathrm{U} 1$ cells: inhibition of inductive effects by the interleukin 1 receptor antagonist. Proc Natl Acad Sci USA 1994, 91(1):108-112.

64. Lane BR, Lore K, Bock PJ, Andersson J, Coffey MJ, Strieter RM, Markovitz DM: Interleukin-8 stimulates human immunodeficiency virus type 1 replication and is a potential new target for antiretroviral therapy. J Virol 2001, 75(17):8195-8202.

65. Osborn L, Kunkel S, Nabel GJ: Tumor necrosis factor alpha and interleukin 1 stimulate the human immunodeficiency virus enhancer by activation of the nuclear factor kappa B. Proc Natl Acad Sci USA 1989. 86(7):2336-2340

66. Chun TW, Engel D, Mizell SB, Ehler LA, Fauci AS: Induction of HIV-1 replication in latently infected CD4+ T cells using a combination of cytokines. J Exp Med 1998, 188(1):83-91.

67. Miller CJ, Shattock RJ: Target cells in vaginal HIV transmission. Microbes and infection / Institut Pasteur 2003, 5(1):59-67.

68. Lederman MM, Offord RE, Hartley O: Microbicides and other topical strategies to prevent vaginal transmission of HIV. Nat Rev Immunol 2006, 6(5):371-382.

69. Doncel GF, Chandra N, Fichorova RN: Preclinical assessment of the proinflammatory potential of microbicide candidates. J Acquir Immune Defic Syndr 2004, 37(Suppl 3):S174-S180.

70. Kaul R, Rebbapragada A, Hirbod T, Wachihi C, Ball TB, Plummer FA, Kimani J, Jaoko W: Genital levels of soluble immune factors with anti-HIV activity may correlate with increased HIV susceptibility. AIDS 2008, 22(15):2049-2051.

71. Ghosh M, Shen Z, Schaefer TM, Fahey JV, Gupta P, Wira CR: CCL20/ MIP3alpha is a novel anti-HIV-1 molecule of the human female reproductive tract. Am J Reprod Immunol 2009, 62(1):60-71.

72. Huskens D, Vermeire K, Vandemeulebroucke E, Balzarini J, Schols D: Safety concerns for the potential use of cyanovirin- $\mathrm{N}$ as a microbicidal anti-HIV agent. Int J Biochem Cell Biol 2008, 40(12):2802-2814.

73. Thompson RC, Ohlsson K: Isolation, properties, and complete amino acid sequence of human secretory leukocyte protease inhibitor, a potent inhibitor of leukocyte elastase. Proc Natl Acad Sci USA 1986, 83(18):6692-6696.

74. Nikolaitchouk N, Andersch B, Falsen E, Strombeck L, Mattsby-Baltzer I: The lower genital tract microbiota in relation to cytokine-, SLPI- and endotoxin levels: application of checkerboard DNA-DNA hybridization (CDH). APMIS 2008, 116(4):263-277.

75. Novak RM, Donoval BA, Graham PJ, Boksa LA, Spear G, Hershow RC, Chen $H Y$, Landay A: Cervicovaginal levels of lactoferrin, secretory leukocyte protease inhibitor, and RANTES and the effects of coexisting vaginoses in human immunodeficiency virus (HIV)-seronegative women with a high risk of heterosexual acquisition of HIV infection. Clin Vaccine Immunol 2007, 14(9):1102-1107.

76. Tsai CC, Emau P, Jiang Y, Agy MB, Shattock RJ, Schmidt A, Morton WR Gustafson KR, Boyd MR: Cyanovirin-N inhibits AIDS virus infections in vaginal transmission models. AIDS Res Hum Retroviruses 2004, 20(1):11-18

77. Stapleton AE, Au-Yeung M, Hooton TM, Fredricks DN, Roberts PL, Czaja CA Yarova-Yarovaya Y, Fiedler T, Cox M, Stamm WE: Randomized, placebocontrolled phase 2 trial of a Lactobacillus crispatus probiotic given intravaginally for prevention of recurrent urinary tract infection. Clin Infect Dis 2011, 52(10):1212-1217.
78. Senok AC, Verstraelen H, Temmerman M, Botta GA: Probiotics for the treatment of bacterial vaginosis. Cochrane Database Syst Rev 2009, (4):CD006289. pub2.

79. Hemmerling A, Harrison W, Schroeder A, Park J, Korn A, Shiboski S, FosterRosales A, Cohen CR: Phase 2a study assessing colonization efficiency, safety, and acceptability of Lactobacillus crispatus CTV-05 in women with bacterial vaginosis. Sex Transm Dis 2010, 37(12):745-750.

doi:10.1186/1471-2180-13-4

Cite this article as: Yamamoto et al:: Homeostatic properties of Lactobacillus jensenii engineered as a live vaginal anti-HIV microbicide. BMC Microbiology 2013 13:4.

\section{Submit your next manuscript to BioMed Central and take full advantage of:}

- Convenient online submission

- Thorough peer review

- No space constraints or color figure charges

- Immediate publication on acceptance

- Inclusion in PubMed, CAS, Scopus and Google Scholar

- Research which is freely available for redistribution

Submit your manuscript at www.biomedcentral.com/submit
( BioMed Central 